\title{
Topographic heterogeneity, hydrodynamics, and benthic community structure: a scale-dependent cascade
}

\author{
Frédéric Guichard*, Edwin Bourget \\ GIROQ, Département de Biologie, Université Laval, Québec, Québec G1K 7P4, Canada
}

\begin{abstract}
The influence of boulder size on flow velocity and rocky shore intertidal macrobenthic civersity and biomass was examined. A $3.6 \mathrm{~m}$ radius area around boulders of different size categories $\left(50-75,75-100\right.$, and $200-250 \mathrm{~cm}$ ) and control sites (no boulders) was divided into six $60^{\circ}$ sectors and 4 distance classes away from boulders $(0-30,30-90,90-180$, and $180-360 \mathrm{~cm}$ ), forming 24 sampling cells for each boulder and control site. Flow velocity patterns near boulders were examined with MarshMcBirney current meters and plaster cylinders immersed in the center of each sampling cell. Sessile organisms in 4 randomly positioned $10 \times 10 \mathrm{~cm}$ quadrats from each sampling cell were sampled. The blotted mass of each species collected was determined for each quadrat ( $n=1440$ ). Downstream of a large boulder, mean flow velocity was half that upstream. This was also the only orientation where flow velocity never reached $>15 \mathrm{~cm} \mathrm{~s}^{-1}$. Similarly, velocity indices obtained from the erosion of plaster cylinders were significantly lower downstream compared to upstream of boulders, and differences were greater for large boulders. Invertebrate biomass decreased significantly downstream of boulders. This effect increased with boulder size, and was significant for the large boulder category $(200-250 \mathrm{~cm})$. Algal biomass was not significantly influenced by boulders, though distribution patterns were analogous to invertebrate biomass. Diversity $\left(H^{\prime}\right)$ peaked along the distance gradient around larger boulders, and generally increased with boulder size. The positive correlation between biomass and the velocity index was stronger with increasing boulder size. The correlation between invertebrate biomass and the flow velocity index was not significant at control sites, but $27.4 \%$ of the variation in invertebrate biomass around large boulders could be explained by the velocity index. These results support the hypotheses that (1) hydrodynamics is a vector linking topographic heterogeneity and community structure, and (2) this cascade (topographic heterogeneity $\rightarrow$ hydrodynamics $\rightarrow$ community structure) is scale-dependent
\end{abstract}

KEY WORDS: Topographic heterogeneity Spatial scales - Benthos - Hydrodynamics C Community structure

\section{INTRODUCTION}

Spatial ecology is a growing field (Levin et al. 1997, Tilman \& Kareiva 1997). With the explicit treatment of space in ecological studies, problems related to spatial variability and spatial scales need to be addressed (Wiens 1989, Levin 1992, Schneider 1994). Experiments testing the influence of environmental variables (physical or biological) on community structure seldom include space and spatial scale explicitly as main treat-

·E-mail: frederic.guichard@giroq.ulaval.ca ments, with the result that 'pattern-oriented' spatial models (Grimm 1994, Grimm et al. 1996) based on environmental variables are difficult to make. Experiments must be designed to test relationships between spatial variability of physical (e.g. current velocity) and biological (e.g. biomass) variables over gradients of spatial scales. In order to test for the existence of such scaling in intertidal habitats, we examined the influence of scales of topographic heterogeneity on hydrodynamic patterns and their influence on 2 community characteristics (biomass and diversity) in a rocky shore intertidal community. 
Although stable over ecological temporal scales, topographic heterogeneity influences the abundance and distribution of organisms by creating refuges against harsh physical (e.g. wind blowdown, Boose et al. 1994; desiccation, Garrity 1984; and ice scouring, Bergeron \& Bourget 1986) and biotic (e.g competition and predation, Garrity \& Levings 1981, Gosselin \& Bourget 1989) conditions. Topographic features can also modify hydrodynamics over very small (Eckman 1979) to regional scales (Wolanski \& Hammer 1988), and control juvenile transport (Rankin et al. 1994), recruitment (Johnson 1994), and feeding rates (Fréchette et al. 1989) of benthic organisms. Few studies have investigated the influence of topographic heterogeneity on community structure at the scale of meters. In marine systems, topographic heterogeneity has been shown to modify community characteristics in soft-bottom communities (Cusson \& Bourget 1997) and benthic fish recruitment by creating favorable local hydrodynamic conditions (Breitburg et al. 1995).

On subarctic rocky shores, glacially deposited boulders are an important source of topographic heterogeneity (Dionne 1972, Drapeau 1990). In the St. Lawrence system in particular, boulders are relatively spherical, and offer the possibility of testing scale effects by using boulders of increasing size. Since biological interactions are limited in subarctic mid intertidal environments (see below), we used these intertidal boulder fields to test the following hypotheses: (1) surrounding bedrock community characteristics (diversity and biomass) are modified as a function of both position (orientation, distance from boulder) and boulder size (scale); (2) the spatial patterns of community characteristics near boulders are correlated with hydrodynamic patterns. Our results show that (1) boulders locally influenced hydrodynamics and spatial distribution of benthic organisms, and (2) boulder size modulates the strength of these relationships. We also present evidence that hydrodynamics was likely a vector linking topographic heterogeneity to community characteristics

\section{METHODS}

Study area. Sainte-Flavie, along the south shore of the St. Lawrence Estuary, Québec, Canada (Fig. 1) was chosen as our study site. A $3 \mathrm{~km}$ long intertidal shore section was selected with the following criteria: (1) it was located along a relatively straight part of the coastline and there were no large scale topographic features nearby to affect the hydrodynamic flow regime, (2) the hydrodynamic regime of the area was under investigation as part of the CHASE project (Coastal Heterogeneity And Scaling Experiments), (3) a rela-

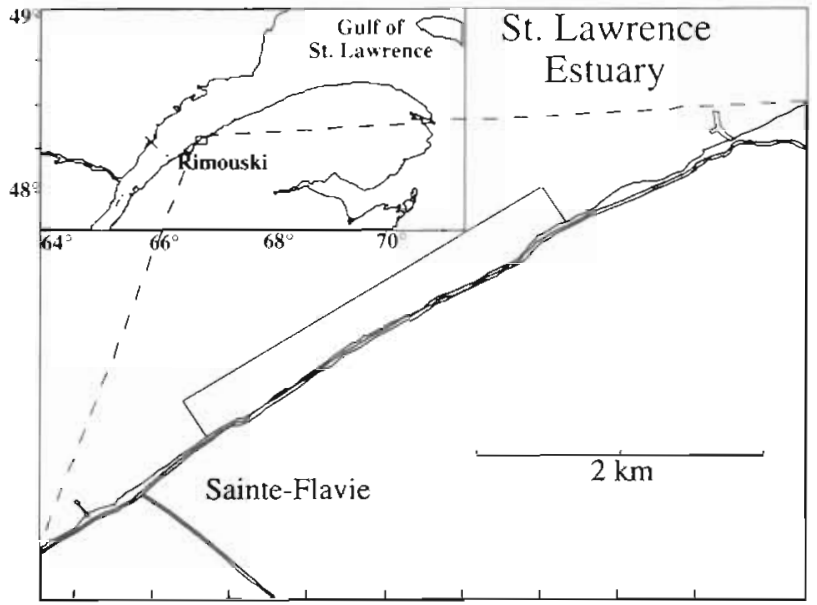

Fig. 1. Study area along the south shore of the St. Lawrence Estuary, Québec, Canada

tively large number of morainic boulders was stranded on the horizontal intertidal bedrock, so that stringent boulder selection criteria could be applied (see below). The study area shore was a weakly inclined rocky platform, with different sized boulders and some fine sediments. Overall, the shoreline of the Estuary was oriented along the $240^{\circ} / 60^{\circ}$ axis relative to magnetic north. The macrobenthic community (31 algal and invertebrate species were identified; Table 1) was dominated by Mytilus edulis and/or Mytilus trossulus, hereafter referred to as Mytilus, indistinguishable by simple morphological examination, and Fucus species Littorina saxatilis and Littorina obtusata were also very abundant. We did not observe any strong correlation among dominant species at the scale of quadrats. Mytilus biomass was weakly correlated with $L$. saxatilis $(\mathrm{r}=0.18 ; \mathrm{p}<0.01)$ and with $L$. obtusata $(\mathrm{r}=0.01$; $\mathrm{p}<0.01$ ), and Fucus biomass was correlated with $L$. obtusata $(r=0.12 ; p<0.01)$. In the mid intertidal of the study area, no known predators or effective competitors of the mussel are known. Semidiurnal tidal range varied from about $2 \mathrm{~m}$ (neap tides) to $4.5 \mathrm{~m}$ (spring tides). In spring, ice scouring is an important disturbance factor, dislodging most exposed organisms (Archambault \& Bourget 1983, Bourget et al. 1985, Bergeron \& Bourget 1986).

Boulder selection. Size categories were determined after a preliminary examination of available boulders. Three size categories of rounded boulders were selected, based on the average of the maximum height, minimum diameter, and maximum diameter: (1) 50 to $75 \mathrm{~cm}$, (2) 75 to $100 \mathrm{~cm}$, and (3) 200 to $250 \mathrm{~cm}$. The control site was an area with no boulders (Fig. 2). For each boulder size category and control, 4 experimental replicate sites were randomly selected from 16 premarked potential sites in the study area, except for the 
large boulder sites, for which only 3 replicate sites corresponded to the criteria (see below). To limit the within- and among-site treatment variability, the following a priori criteria were established: (1) each boulder dimension (height, length, width) should not exceed $2 \times$ the others, (2) selected boulders must stand on bedrock, and (3) sites must be free of any topographic irregularity (other boulders and crevices) larger than $30 \mathrm{~cm}$ within a radius of $5 \mathrm{~m}$, and (4) sites must be free of a sediment layer thicker than $2 \mathrm{~cm}$, and of water (tide pools $>2 \mathrm{~cm}$ depth) over a minimum of $60 \%$ of the total area. The diameter of selected boulders ranged from 53 to $73 \mathrm{~cm}$ (small boulders), 85 to $98 \mathrm{~cm}$ (medium boulders) and 200 to $250 \mathrm{~cm}$ (large boulders). The area around the randomly selected sites was divided into six $60^{\circ}$ sectors relative to magnetic north, and 4 classes of distance from boulders $(30,90$, $180,360 \mathrm{~cm}$ ), to examine the distribution of organisms in the vicinity of boulders, forming 24 sampling cells around each boulder. At each control site we structured the sampling around a medium size circle
( $75 \mathrm{~cm}$ ) and obtained a comparable number of sampling cells (Fig. 2).

Flow measurements. Dissolution of plaster cylinders: We used plaster cylinders anchored in the center of each sampling cell ( 24 cells per boulder or control site; $\mathrm{n}=360$; Fig. 2) over 24 h ( 2 full semi-diurnal tidal cycles) to obtain a relative measure of flow velocity. Plaster mass loss was shown to be linearly related to mean water velocity (Muus 1968, Komatsu \& Kawai 1992, Thompson \& Glenn 1994). Each cylinder was vertically anchored $2 \mathrm{~cm}$ above the bottom using a metal rod (4 mm diam.) running through it that was solidly anchored to the intertidal bedrock. Each cylinder $(8 \mathrm{~cm}$ long $\times 2.5 \mathrm{~cm}$ diam.) was made from plaster of Paris (Lepage ${ }^{T M}$, Brompton, Ontario, Canada). The ends were covered with epoxy to prevent dissolution and maintain a near constant exposed area during the immersion period. The cylinders were dried for $21 \mathrm{~d}$ at ambient temperature then weighed before immersion and then dried $21 \mathrm{~d}$ and reweighed after retreival to obtain the dry mass loss $( \pm 0.005 \mathrm{~g})$. All plaster cylin-

Table 1. Species of the macrobenthic community at the study site. Each species is listed with its frequency of occurrence and mean biomass in quadrats, and its total and maximum biomass in all quadrats $(n=1440)$

\begin{tabular}{|c|c|c|c|c|c|}
\hline \multirow{2}{*}{$\begin{array}{l}\text { Species } \\
\text { Littorina saxatilis }\end{array}$} & \multirow{2}{*}{$\begin{array}{c}\begin{array}{c}\text { Frequency } \\
(\%)\end{array} \\
99.58\end{array}$} & \multicolumn{2}{|c|}{$\begin{array}{c}\text { Mean }( \pm \mathrm{SD}) \text { biomass } \\
(\mathrm{g})\end{array}$} & \multirow{2}{*}{$\begin{array}{l}\text { Total biomass } \\
\qquad(g) \\
858.607\end{array}$} & \multirow{2}{*}{$\begin{array}{c}\text { Maximum } \\
\text { biomass }(\mathrm{g}) \\
8.878\end{array}$} \\
\hline & & 0.59626 & $(0.54378)$ & & \\
\hline Fucus sp. & 88.26 & 26.49733 & $(39.80772)$ & 38130.000 & 324.010 \\
\hline Littorina oblusata & 86.04 & 0.65898 & $(1.00810)$ & 948.277 & 14.590 \\
\hline Mytilus edulis (and/or trossulus) & 86.04 & 20.56315 & $(26.79250)$ & 29611.000 & 220.140 \\
\hline Macoma balthica & 43.54 & 0.10758 & $(0.36761)$ & 154.917 & 9.971 \\
\hline Acmaea testidunalis & 23.54 & 0.03124 & $(0.11471)$ & 44.978 & 1.439 \\
\hline Mesodesma arctatum & 7.15 & 0.09310 & $(1.01557)$ & 134.060 & 21.131 \\
\hline Wya arenaria & 6.39 & 0.01038 & $(0.06664)$ & 14.950 & 1.385 \\
\hline Cistena granulata & 5.21 & 0.01085 & $(0.06551)$ & 15.622 & 0.964 \\
\hline Petalonia fascia & 3.75 & 0.03165 & $(0.34039)$ & 45.582 & 8.573 \\
\hline Lacuna vincta & 3.47 & 0.00257 & $(0.02326)$ & 3.706 & 0.660 \\
\hline Ulva lactuca & 1.39 & 0.01195 & $(0.17964)$ & 17.214 & 5.563 \\
\hline Skenea planorbis & 0.97 & 0.00004 & $(0.00055)$ & 0.058 & 0.014 \\
\hline Antithamnion sp. & 0.76 & 0.01014 & $(0.36582)$ & 14.598 & 13.878 \\
\hline Bunodactis stella & 0.76 & 0.00210 & $(0.03355)$ & 3.017 & 0.785 \\
\hline Balanus crenatus & 0.69 & 0.00102 & $(0.01449)$ & 1.473 & 0.290 \\
\hline Hiatella arctica & 0.69 & 0.00141 & $(0.02719)$ & 2.032 & 0.920 \\
\hline Polysiphonia sp. & 0.63 & 0.00093 & $(0.02358)$ & 1.342 & 0.665 \\
\hline Rhodomela confervoides & 0.56 & 0.00097 & $(0.01714)$ & 1.401 & 0.425 \\
\hline Scytosiphon lomentaria & 0.49 & 0.00256 & $(0.05367)$ & 3.687 & 1.807 \\
\hline Margantes helicinus & 0.21 & 0.00003 & $(0.00101)$ & 0.043 & 0.038 \\
\hline Enteromorpha sp. & 0.14 & 0.00047 & $(0.01477)$ & 0.680 & 0.544 \\
\hline Hydrobia minuta & 0.14 & 0.00001 & $(0.00025)$ & 0.013 & 0.008 \\
\hline Acrosiphonia arcta & 0.07 & 0.00027 & $(0.01023)$ & 0.388 & 0.388 \\
\hline Aeolidia papillosa & 0.07 & 0.00115 & $(0.04380)$ & 1.662 & 1.662 \\
\hline Halosaccion ramentaceum & 0.07 & 0.00001 & $(0.00037)$ & 0.014 & 0.014 \\
\hline Desmarestia aculeata & 0.07 & 0.00071 & $(0.02699)$ & 1.024 & 1.024 \\
\hline Elachista fucicola & 0.07 & 0.00002 & $(0.00063)$ & 0.024 & 0.024 \\
\hline Littorina littorea & 0.07 & 0.00024 & $(0.00922)$ & 0.350 & 0.350 \\
\hline Porphyra sp. & 0.07 & 0.00009 & $(0.00343)$ & 0.130 & 0.130 \\
\hline Semibalanus balanoides & 0.07 & 0.00036 & $(0.01368)$ & 0.519 & 0.519 \\
\hline
\end{tabular}




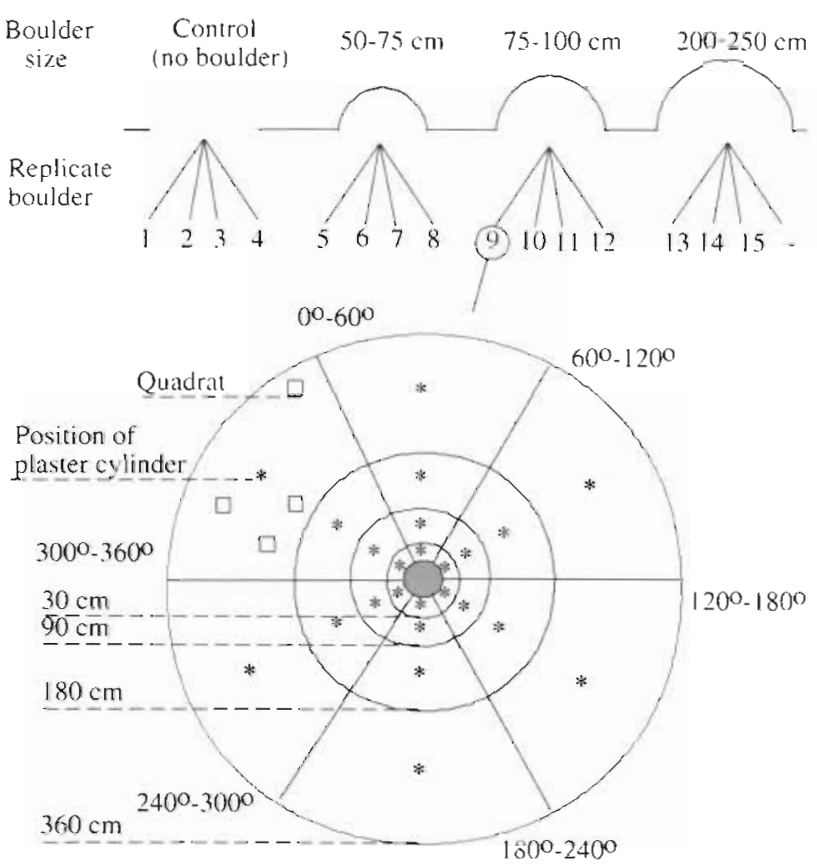

Fig. 2. Schematic representation of the sampling design. Orientations are relative to magnetic north

ders were immersed on 18 August 1994. Dry mass loss (initial - end weight in $\mathrm{g}$ ) was used as a relative index of mean water velocity.

Current velocity measurements: Current velocities were also measured around one randomly selected site for each size category, simultaneously using 2 MarshMcBirney electromagnetic current meters, linked to a EMOBS (self-contained ocean data acquisition system; Dalhousie University, Nova Scotia, Canada). The 2 current meters were placed $10 \mathrm{~cm}$ above the substratum. During each $12 \mathrm{~h}$ mooring period, both current meters were placed at the site on opposite sides $\left(0^{\circ} / 180^{\circ}\right.$ or $90^{\circ} / 270^{\circ}$ relative to magnetic north) and at a defined distance from the boulder $(50$ or $150 \mathrm{~cm}$ ). The 4 positions [ 2 orientation axes ( $u_{x}$ and $u_{y}$ ) and 2 distances] around each site were investigated within a $48 \mathrm{~h}$ period (4 tidal cycles). Each site was investigated at 2 randomly selected dates, a first time between 2 and 16 August 1994, and a second time between 17 and $24 \mathrm{Au}-$ gust 1994. The datalogger was programmed to record the average of 60 velocity measurements $\left(60 u_{x}\right.$ and $60 u_{y}$ ) measured over $1 \mathrm{~min}$ by each probe, at $10 \mathrm{~min}$ intervals, when water depth was greater than $50 \mathrm{~cm}$

Community characteristics. Benthic community sampling at each experimental site was carried out between 17 July and 8 August 1994. The sampling period was kept short to minimize biases from temporal changes in community structure. At each cel.l of each boulder and control site, four $10 \times 10 \mathrm{~cm}$ quadrats were randomly chosen ( $\mathrm{n}=1440$ ) from random polar coordinates. All organisms (invertebrates and algae) were taken from each quadrat, except for encrusting species, which could not be collected effectively, and the $\%$ cover was estimated visually by one observer. Samples were kept frozen at $-18^{\circ} \mathrm{C}$ until analysis. They were then sieved using $1 \mathrm{~mm}$ mesh sieves and all sessile or sedentary individuals were sorted and identified to species level, or the lowest taxonomic unit possible. The blotted mass of all species in each quadrat was weighed using a Mettler 360 balance $( \pm 0.005 \mathrm{~g})$. A Shannon diversity index $\left(H^{\prime}\right)$, based on biomass (Frontier \& Pichod-Viale 1993), was computed for each quadrat. An evenness index was computed as $H^{\prime} / H_{\text {max }}^{\prime}$, where $H_{\text {max }}^{\prime}$ is the diversity index computed for an evenly distributed biomass among species in each quadrat.

Some potentially influential environmental variables were also measured. The covariables in each quadrat were small-scale topographic heterogeneity (rugosity, see below), height above the zero tidal level, \% cover of sofi substratum, and \% water cover (pools). Since small-scale topography (1 to $10 \mathrm{~cm}$ ) has been shown to influence rocky shore benthic communities, especially in regions exposed to ice scouring (Chabot \& Bourget 1988, Bourget et al. 1994, Archambault \& Bourget 1996), substratum heterogeneity within quadrats was determined using a woodworker's profiler (1 mm resolution). This instrument consists of 150 metal rods (1 $\mathrm{mm}$ diam., $10 \mathrm{~cm}$ high) tightly aligned over $15 \mathrm{~cm}$, capable of moving verticaly and individually, thus allowing the profiler to retain the contour of any surface along a $15 \mathrm{~cm}$ long transect. Profiles along two $10 \mathrm{~cm}$ perpendicular transects were obtained for each quadrat. The profiles were immediately traced on paper in the field, then digitized in the laboratory (72 dpi resolution). For every quadrat transect, heterogeneity indices were computed at 10 spatial resolutions, from 1 to $50 \mathrm{~mm}$, using the box-counting method (Hastings \& Sugihara 1993). For each quadrat, we took as a scale-specific index of heterogeneity the mean number of boxes $(\mathrm{N})$ needed to cover profiles at each resolution (box size), as computed by a box-counting algorithm. Similar single scale indices of heterogeneity have previously been used in ecological studies (McCormick 1994). The fractal dimension (D), computed as the slope of the regression line $(n=12)$ of $\log (N)$ against $\log (1 / S)$, where $S$ is the box size, was also used as an index of substratum heterogeneity, which varied from 1 (straight line) to 1.12 in our samples.

Analysis. The null hypotheses that there was no effect of boulder size, orientation and distance on dry mass loss of plaster cylinders, the biomass of each dominant species, invertebrate biomass, algal biomass, 
diversity $\left(H^{\prime}\right)$, evenness $\left(H^{\prime} / H^{\prime}\right.$ max $)$, and the proportion of species other than Mytilus and Fucus sp., were tested by a mixed factorial ANOVA model, using an SAS statistical package (SAS 1988). Normality and homoscedasticity were examined on residuals. Square-root transformation was applied to invertebrate biomass to achieve these postulates. Replicate sampling design allowed us to discriminate between treatment effects and random variability. For the latter we computed among-boulder variability [boulder (boulder size)\}, within boulder (i.e. among sampling cells) variability Iorjentation $\times$ distance $\times$ boulder(boulder size) or orientation $\times$ boulder(boulder size) + distance $\times$ boulder(boulder size), depending on the model], and within-sampling-cell variability (error term). The within- and among-boulder random variability (random factors) were not interpreted. Covariables were not included in the ANOVA model since they violated at least 1 of 3 conditions: (1) significant, and (2) linear effect on the dependent variable, and (3) no interaction with main treatments. We used a stepwise multivariate regression model using JMP statistical software (SAS 1994) to determine variation of invertebrate biomass, algal biomass and $H^{\prime}$ explained by covariates. The presence of autocorrelated spatial structure was visually investigated from semivariograms computed for each control site, where the 96 quadrats were positioned in a cartesian coordinates system before the computation of omnidirectional semivariograms with Variowin geostatistical software (Pannatier 1996). We did not observe any consistent increase of the semivariance as a function of the spatial lag (i.e. autocorrelation). Autocorrelation would have violated assumptions of independence of samples (Fortin et al. 1989, Dutilleul 1993). Correlation between biological and hydrodynamic (velocity index) variables was tested using Pearson correlation coefficients between velocity index values and mean biomass or diversity in each sampling cell. In order to test for the scale-dependent relationship between flow velocity and biological variables, correlation coefficients were computed for each boulder size category and significant differences among coefficients were tested using a $z$-transformation (Sokal \& Rohlf 1981).

\section{RESULTS}

\section{Flow patterns}

Current velocity at $10 \mathrm{~cm}$ above the substratum and at water depth greater than $50 \mathrm{~cm}$ ranged from $<1$ to $50 \mathrm{~cm} \mathrm{~s}^{-1}$ with an average velocity of $6 \mathrm{~cm} \mathrm{~s}^{-1}$. Mean orientation at the control site was $68^{\circ} \pm 51^{\circ}$ relative to magnetic north, i.e. approximately eastward and par-
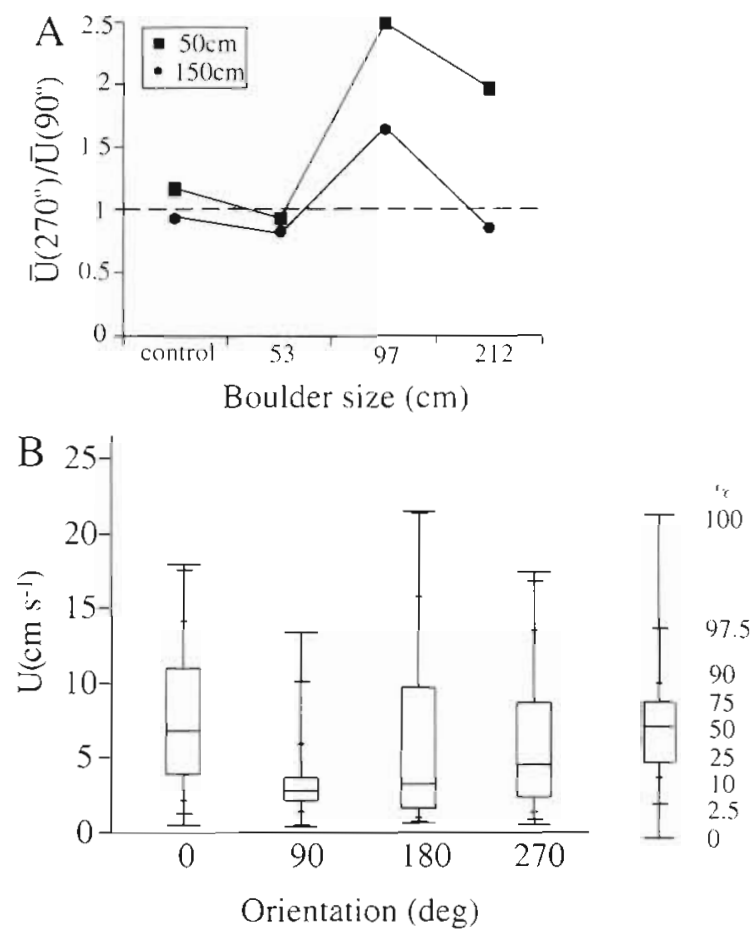

Fig. 3. Current meter data represented as (A) ratio of upstream to downstream mean velocity, and (B) quantile box plot (see legend on the right) abtained for 4 orientations at $50 \mathrm{~cm}$ distance from a large boulder

allel to the shore. Both flow orientation and velocity remained relatively unchanged within one semi-diurnal tidal cycle. Thus, we did not observe a flow reversal or velocity decrease near the time of high tide. These data are in agreement with long time series current measurements at the scale of the study area (Guichard unpubl, data).

There were well-defined flow velocity patterns around boulders. Near the boulders $(50 \mathrm{~cm}$ from the edge), the ratios of mean velocity upstream to mean velocity downstream (see 'Methods') increased with boulder size (near 1 at control and small boulder sites, to 1.97 around the large boulders) (Fig. 3A). The high ratio value near the medium boulder could have been caused by unsuspected local characteristics of the flow, since even at $150 \mathrm{~cm}$ from the boulder, the ratio was still relatively high (Fig $3 \mathrm{~A}$ ). This relation between boulder size and velocity ratio (Fig. 3A) holds for velocity values averaged over $24 \mathrm{~h}$; no pattern was detected for values averaged over shorter time intervals. Similarly, orientation significantly influenced the flow velocity index (Table 2, Fig. 4A). Plaster cylinders at $90^{\circ}$ and $150^{\circ}$ (downstream side) were significantly less eroded than cylinders at $30^{\circ}$ and $210^{\circ}$ (opposite directions). This effect was detected graphically only around large boulders (Fig. 4B). 
A
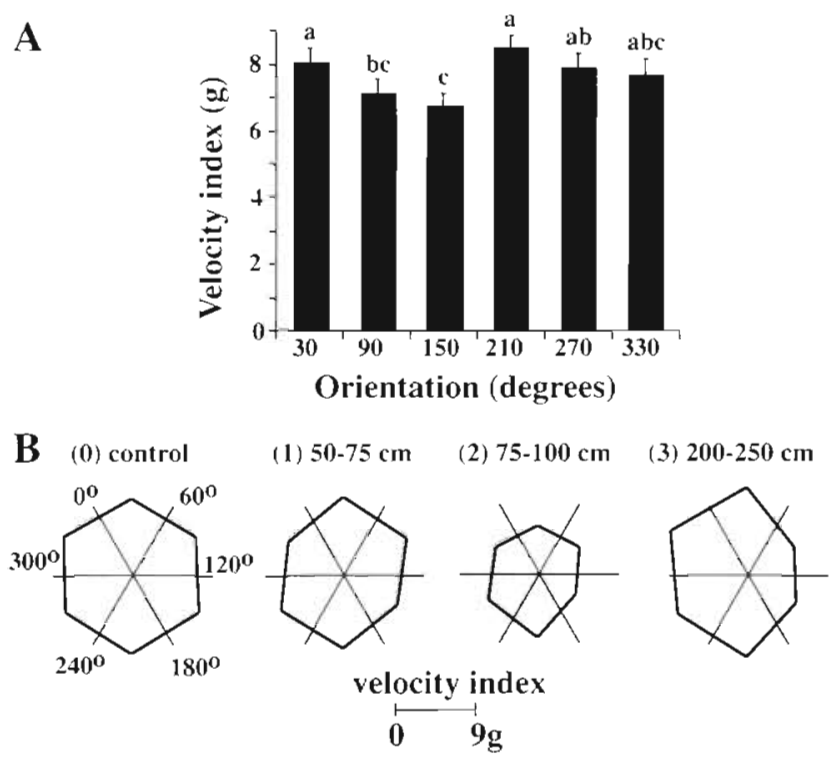

Fig. 4. Mean velocity index for 6 equal orientation sectors around boulders. (A) All boulder size categories combined. Statistically different orientation categories are indicated by different letters (+SE). (B) Velocity index for each boulder size category

Table 2. Analysis of variance showing the effect of boulder size (Bsize), orientation (Ort), distance (Dst), among$[\mathrm{B}($ Bsize $)]$ and within-boulder variability $[\mathrm{Ort} \times \mathrm{B}(\mathrm{Bsize})$ and Dst $\times B(B s i z e)]$, on velocity index (initial - end mass of plaster cylinders). "Significant at $5 \%$ and $\cdots 0.1 \%$ levels

\begin{tabular}{|lrrrc|}
\hline Source of variation & df & \multicolumn{1}{c}{ MS } & $F$ & $p$ \\
\hline Bsize & 3 & 152.2675 & 1.5862 & 0.2486 \\
B(Bsize) & 11 & 95.8618 & 10.5968 & $0.0001 . \cdots$ \\
Ort & 5 & 28.1546 & 3.1510 & $0.0143^{.}$ \\
Dst & 3 & 1.3704 & 0.2357 & 0.8708 \\
Ort $\times$ Dst & 15 & 7.1816 & 1.2607 & 0.2326 \\
Bsize $\times$ Ort & 15 & 11.4832 & 1.2852 & 0.2430 \\
Bsize $\times$ Dst & 9 & 3.2384 & 0.5571 & 0.8215 \\
Bsize $\times$ Ort $\times$ Dst & 45 & 5.1864 & 0.9105 & 0.6347 \\
Ort $\times$ B(Bsize) & 55 & 8.9340 & 1.5683 & 0.0159 \\
Dst $\times$ B(Bsize) & 33 & 5.8130 & 1.0204 & 0.4463 \\
Error & 165 & 5.6965 & & \\
Corrected total & 359 & & & \\
\hline
\end{tabular}

Current velocity above $10 \mathrm{~cm} \mathrm{~s}^{-1}$ occurred less than $3 \%$ of the time on the downstream side, $50 \mathrm{~cm}$ from a large boulder. The velocity was at least this high $20 \%$ of the time for every other orientation (Fig. 3B).

\section{Community characteristics}

There was a signifjcant interaction effect of boulder size and distance from boulders on diversity $H^{\prime}$ Invertebrate biomass was significantly influenced by the
Table 3. Analysis of variance showing the effect of boulder size (Bsize), orientation (Ort), distance (Dst), among$[B(B s i z e)]$ and within $[B \times$ Ort $\times$ Dst (Bsize) $]$ boulder variability, on invertebrate biomass $(\mathrm{g})$, algal biomass $(\mathrm{g})$ and diversity $\left(H^{\prime}\right)$. Squared-root transformation was applied to invertebrate biomass to achieve normality and homoscedasticity. Significant at $\cdot 1 \%$ and $\cdots 0.1 \%$ levels

\begin{tabular}{|c|c|c|c|c|}
\hline Source of variation & df & MS & $F$ & $\mathrm{p}$ \\
\hline \multicolumn{5}{|l|}{ Invertebrate biomass } \\
\hline Bsize & 3 & 116.6878 & 0.7226 & 0.5592 \\
\hline $\mathrm{B}(\mathrm{Bsize})$ & 11 & 161.4806 & 20.4511 & $0.0001 \cdots$ \\
\hline Ort & 5 & 8.5087 & 1.0776 & 0.3732 \\
\hline Dst & 3 & 7.2462 & 0.9177 & 0.4329 \\
\hline Ort $\times$ Dst & 15 & 7.0592 & 0.8940 & 0.5715 \\
\hline Bsize $\times$ Ort & 15 & 17.6795 & 2.2391 & $0.0058^{\cdots}$ \\
\hline Bsize $\times$ Dst & 9 & 6.6014 & 0.8360 & 0.5835 \\
\hline Bsize $\times$ Ort $\times$ Dst & 45 & 8.4313 & 1.0678 & 0.3663 \\
\hline B $\times$ Ort $\times$ Dst (Bsize $)$ & 253 & 7.8959 & 1.5395 & $0.0001 \cdots$ \\
\hline Error & 1080 & 5.1290 & & \\
\hline Corrected total & 1439 & & & \\
\hline \multicolumn{5}{|l|}{ Algal biomass } \\
\hline Bsize & 3 & 83975.6283 & 3.0907 & 0.0718 \\
\hline $\mathrm{B}(\mathrm{Bsize})$ & 11 & 27169.0219 & 18.5805 & $0.0001 \cdots$ \\
\hline Ort & 5 & 3288.2969 & 2.2488 & 0.0501 \\
\hline Dst & 3 & 1191.1174 & 0.8146 & 0.4868 \\
\hline Ort $\times$ Dst & 15 & 2366.0455 & 1.6181 & 0.0692 \\
\hline Bsize $\times$ Ort & 15 & 2240.2021 & 1.5320 & 0.1369 \\
\hline Bsize $\times$ Dst & 9 & 689.8247 & 0.4718 & 0.9984 \\
\hline Bsıze $\times$ Ort $\times$ Dst & 45 & 879.2227 & 0.6013 & 0.8729 \\
\hline $\mathrm{B} \times$ Ort $\times$ Dst $($ Bsize $)$ & 253 & 1462.3215 & 1.2837 & $0.0045 \cdots$ \\
\hline Error & 1080 & 1.139 .1335 & & \\
\hline Corrected total & 1439 & & & \\
\hline \multicolumn{5}{|l|}{ Diversity $\left(H^{\prime}\right)$} \\
\hline Bsize & 3 & 0.8146 & 1.6271 & 0.2396 \\
\hline B(Bsize) & 1.1. & 0.5007 & 2.5964 & $0.0038^{\cdots}$ \\
\hline Ort & 5 & 0.2273 & 1.1786 & 0.3201 \\
\hline Dst & 3 & 0.2965 & 1.5378 & 0.2052 \\
\hline Ort $\times$ Dst & 15 & 0.10434 & 0.5413 & 0.9157 \\
\hline Bsize $\times$ Ort & 15 & 0.1554 & 0.8061 & 0.6706 \\
\hline Bsize $\times$ Dst & 9 & 0.6234 & 3.2332 & $0.0010^{*}$ \\
\hline Bsize $\times$ Ort $\times$ Dst & 45 & 0.2499 & 1.2961 & 0.1116 \\
\hline $\mathrm{B} \times$ Ort $\times$ Dst(Bsize) & 253 & 0.1928 & 1.2659 & $0.0069^{\cdots}$ \\
\hline Error & 1080 & 0.1523 & & \\
\hline Corrected total & 1439 & & & \\
\hline
\end{tabular}

interaction between boulder size and orientation around boulders (Table 3). Boulder size, orientation, and the interaction between orientation and distance also showed a trend toward influencing algal biomass (but $0.05<\mathrm{p}<0.1$ ). There was significant variability among and within boulders for $H^{\prime}$, invertebrate biomass and algal biomass.

\section{Influence of boulder size}

There was a trend toward decreasing mean algal and invertebrate biomass, and increasing mean diver- 
A

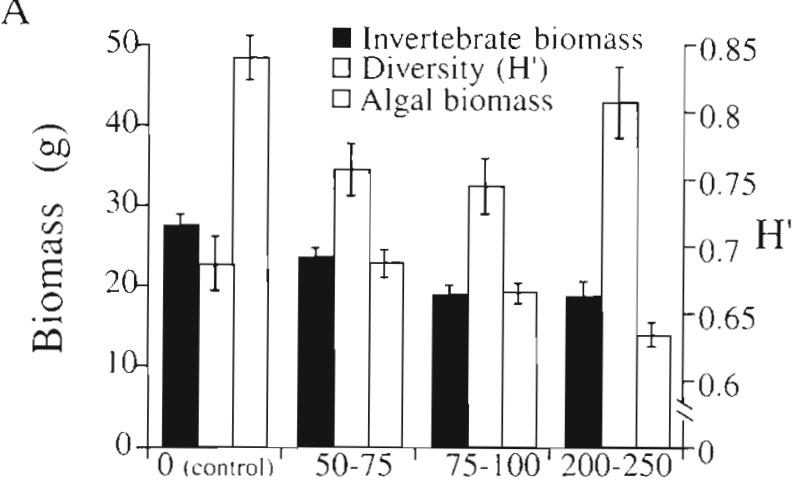

$\mathrm{B}$

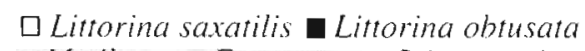

B $\quad$ Mytilus $\square$ Fucus sp. $\square$ Other species
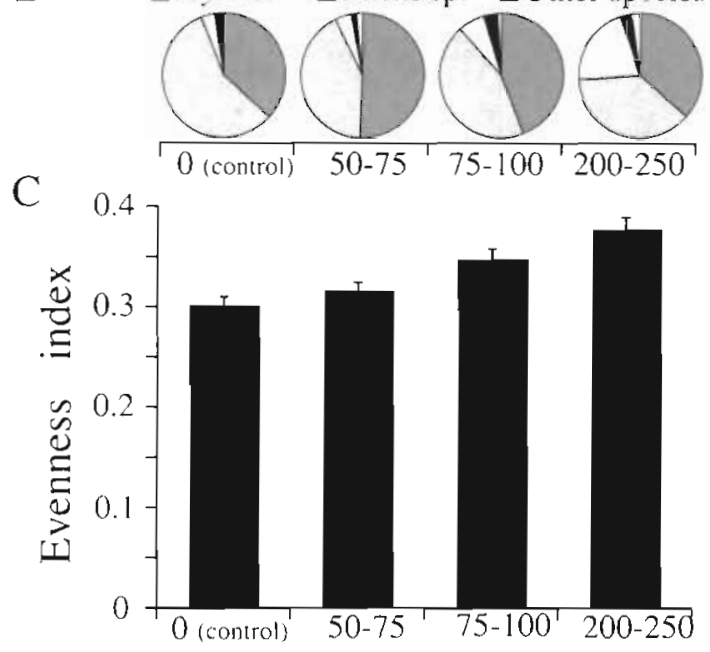

Boulder size $(\mathrm{cm})$

Fig. 5. Influence of boulder size (A) on mean invertebrate biomass, algal biomass, and $H^{\prime},(B)$ on mean proportion of dominant species, and $(\mathrm{C})$ on evenness index $\left(H^{\prime} / H^{\prime} \max +\mathrm{SE}\right)$

sity with increasing boulder size (Fig. 5A) In general, the proportion of Fucus sp. and Mytilus biomass in the community decreased with boulder size, while other species biomass increased from $6 \%$ at control sites to $26 \%$ around large boulders (but $\mathrm{p}>0.05$; Fig. 5B). The evenness $\left(H^{\prime} / H^{\prime}{ }_{\text {max }}\right)$ of biomass increased with boulder size (but $p>0.05 ;$ Fig. $5 \mathrm{C}$ ). Boulder size together with mean height above the zero level were good predictors of mean algal biomass within a given perimeter $(<3.6 \mathrm{~m})$ (Fig. 6).

\section{Influence of orientation}

The negative effect of boulder size on invertebrate biomass was significant at all orientations except between $240^{\circ}$ and $360^{\circ}$ (Fig. 7B). Invertebrate biomass values were significantly lower on the downstream

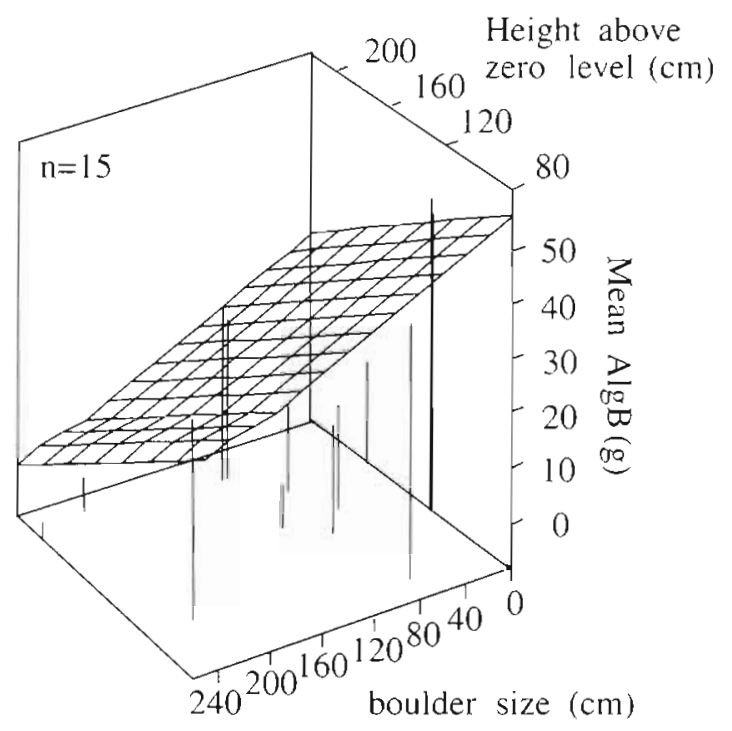

Fig. 6. Relationship between algal biomass (Mean AlgB), boulder size and height above zero tidal level (mean algal biomass $=72.56-0.11$ (boulder size) -0.21 (height); $R^{2}=0.48$; $p<0.05$ ) of all boulders and control sites. Algal biomass values were averaged for each boulder and control site before the regression analysis was performed

side compared to the upstream side of large boulders (Fig. 7A) and invertebrate biomass on the downstream side of boulders decreased with boulder size. Fig. 7B also shows that Mytilus was responsible for invertebrate biomass decrease as a function of boulder size. A similar pattern was observed for algal biomass, almost exclusively composed of Fucus sp. (Fig. 7A). $H^{\prime}$ was not significantly influenced by orientation.

Influence of distance from boulders

While there was a trend toward increasing diversity as a function of boulder size (Fig. 5A), the diversity peak was generally displaced along the distance gradient with increasing boulder size (Fig. 8). A similar trend was observed for the evenness index (Fig. 8).

\section{Influence of covariables}

Multiple stepwise regression carried out for covariable effects $(\%$ cover of soft substratum, $\%$ water cover, height above zero tidal level, substratum heterogeneity at $1 \mathrm{~cm}$ resolution) on biological variables $\left(H^{\prime}\right.$, invertebrate biomass, algal biomass) showed that all covariables together could explain $25.4 \%$ of the invertebrate biomass variability, $9.5 \%$ of algal biomass variability and $3.7 \%$ of $H^{\prime}$ variability. For invertebrate biomass, \% cover of soft substratum was the most influ- 
Invertebrate biomass (g) Algal biomass (g)

A
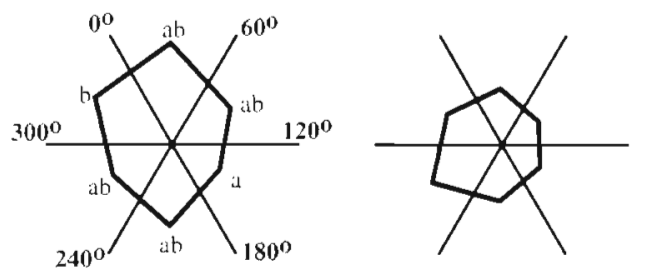

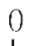

Biomass (g)

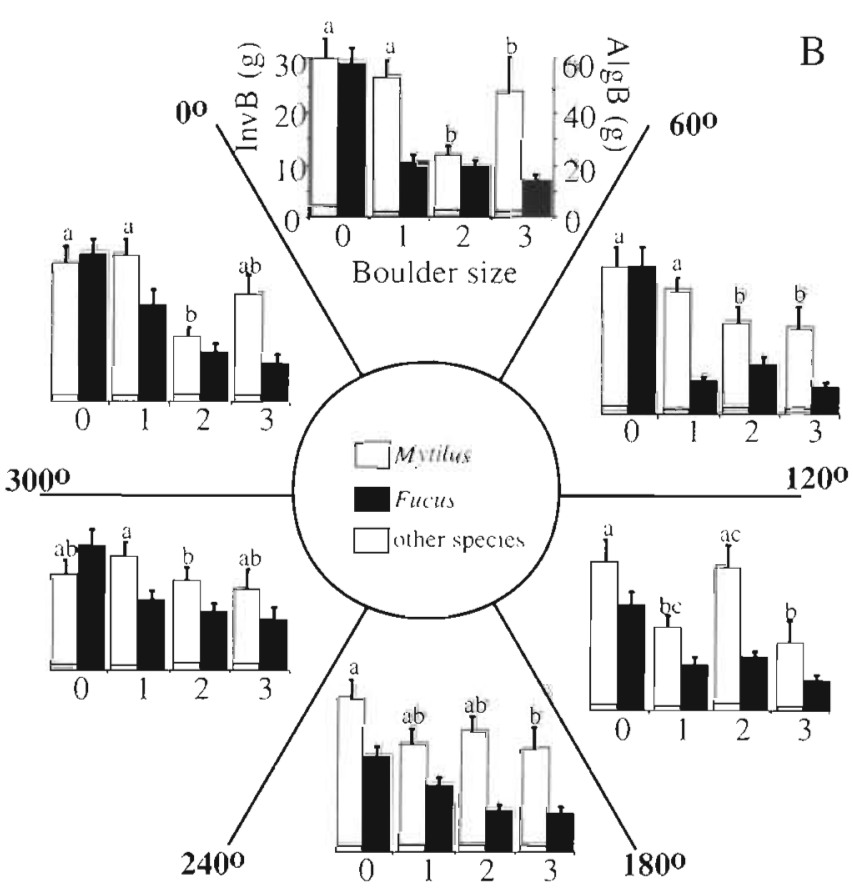

Fig. 7 Mean invertebrate biomass (InvB) and algal biomass (AlgB) for the 6 orientation categories (A) around large boulders and $(B)$ as a function of boulder size categories (invertebrate biomass, first series; algal biomass, second series: $+S E$ ], with each bar represented as the sum of dominant and other species. Orientation categories (A) or boulder size categories (B) with significantly different invertebrate biomass values are indicated by different letters

ential covariable $\left(R^{2}=0.137, p<0.0001\right)$, and height above zero tidal level alone explained $6.15 \%$ of algal biomass variability.

Relationship between. flow velocity index and biological variables

There was no direct effect of boulder size on velocity index (Table 2), but boulder size positively influenced the correlation between velocity index and the biomass values for invertebrates and algae (Fig. 9A). For example, $r$ values between velocity index and invertebrate biomass were significantly larger around large boulders than at control sites (chi-square test of homogeneity of coefficients, $p<0.001$; pairwise comparisons of $z$-transformed coefficients; Fig 9A). Near large boulders, the variance and maximum invertebrate biomass increased with increasing velocity, and the following regression model best described this relationship between invertebrate biomass and velocity index: invertebrate biomass $=0.18(\text { velocity index })^{2}-$ 0.51 (velocity index $)+7.37\left(R^{2}=0.274 i p<0.001\right)$ (Fig. 9B). No significant correlation coefficient between velocity index and $H^{\prime}$ was observed though there was a trend toward larger negative correlations with increasing boulder size.

\section{DISCUSSION}

Our results support the hypothesis that topographic heterogeneity in the form of boulders affects local hydrodynamics and spatial variations in community characteristics. We have shown that flow velocity and spatial patterns of biomass around boulders were correlated (Fig. 9). Moreover, boulder size influenced (1) flow velocity patterns, (2) invertebrate biomass and diversity patterns, and (3) the relationship between flow velocity and invertebrate biomass.

\section{Topographic scales and hydrodynamics}

In marine habitats, the influence of topographic heterogeneity on hydrodynamics has been studied at small scales (e.g. mm and cm) (Eckman 1983, Butman 1987. Abelson et al. 1993, Worcester 1995, Harvey \& Bourget 1997; see Nowell \& Jumars 1984 for a review) and at large scales (km) (Genin et al. 1986, Wolanski \& Hammer 1988, Alvarez et al. 1994). However, to our knowledge hydrodynamic patterns induced by a gradient of topographic scales, at or near the metre scale have not been studied extensively. Ferrier et al. (1996) examined flow patterns around an $8 \mathrm{~m}$ reef and showed the importance of bottom friction in shallow water Flow velocity has also been examned around boulders in an oyster reef habitat where downstream velocity reduction was observed around boulders 30 to $75 \mathrm{~cm}$ in diameter (Breitburg et al. 1995).

The effect of protruding boulders on hydrodynamics can be compared to cylinders placed perpendicular to the flow. There has been much research on this phenomenon, both theoretical and empirical. The flow structure in relation to the Reynolds number $(R e)$ has previously been investigated. $R e$ is a non dimensional characteristic of flow (Tritton 1988) defined as $R e=$ $D U / \mu$, where $D$ is equal to the diameter of the cylinder, $U$ is the mean ambient flow velocity, and $\mu$ is the kine- 
matic viscosity. Re values reflect flow velocity and turbulence patterns around cylindrical objects. At Re between 4 and 40, 2 eddies are formed behind cylinders and do not move downstream. At $\operatorname{Re}=40$, the wake of the cylinder becomes unsteady and eddies are formed alternatively on one side and then on the other side of the cylinder (Kármán vortex street), so that only 1 eddy is present at a given time. Instability grows with $\mathrm{Re}$ in the wake of cylinders, leading to a turbulent wake once $\operatorname{Re}>400$. Near $\operatorname{Re}=10^{5}$, another threshold is observed and the entire boundary layer becomes turbulent. This results in a narrower wake and a turbulent separation of flow from the walls of cylinders (Vogel 1984 , Denny 1988, Tritton 1988). In our study, the boulders can be roughly compared to cylinders perpendicular to the flow; given an ambient water velocity of $5.25 \mathrm{~cm} \mathrm{~s}^{-1}$, a kinematic viscosity of $0.01 \mathrm{~cm}^{2} \mathrm{~s}^{-1}$, and mean boulder sizes of $64 \mathrm{~cm}$ (small), $93 \mathrm{~cm}$ (medium) and $221 \mathrm{~cm}$ (large), then Re values are $3.3 \times 10^{4}, 4.88 \times 10^{4}$ and $1.16 \times 10^{5}$ respectively. Thus, large boulders $(200$ to $250 \mathrm{~cm}$ of diameter) were the only boulder sizes producing a completely turbulent hydrodynamic regime according to $\mathrm{Re}$ values. Only around large boulders were both velocity indices and current meter values consistently reduced on the downstream side, in agreement with this interpretation. These observations suggest the existence of a boulder size threshold (boulders of $190 \mathrm{~cm}$ diameter) above which hydrodynamic flow changes drastically. The irregular boulder shape and the roughness of both boulder surface and the surrounding substratum prevent us from establishing a precise relationship between classical fluid mechanics theory and hydrodynamic patterns around boulders (Vogel 1984, Lighthill 1986, Granger 1995, Ferrier et al, 1996). Here we use the non dimensional Reynolds number as a rough index to understand how scaling-up topographic heterogeneity may influence hydrodynamics, especially when this scaling-up causes Re to vary around threshold values.

\section{Flow velocity and community characteristics}

Two processes related to flow could explain biomass changes: (1) a direct effect of flow on the adhesion of individuals (Butman 1986, Denny 1988, Abelson 1994); and (2) an indirect effect of flow on food availability, that depends on food flux and feeding rate (Jumars \& Nowell 1984, Nowell \& Jumars 1984). We found that invertebrate biomass was positively correlated with
A $0-30 \mathrm{~cm}$

B $30-90 \mathrm{~cm}$

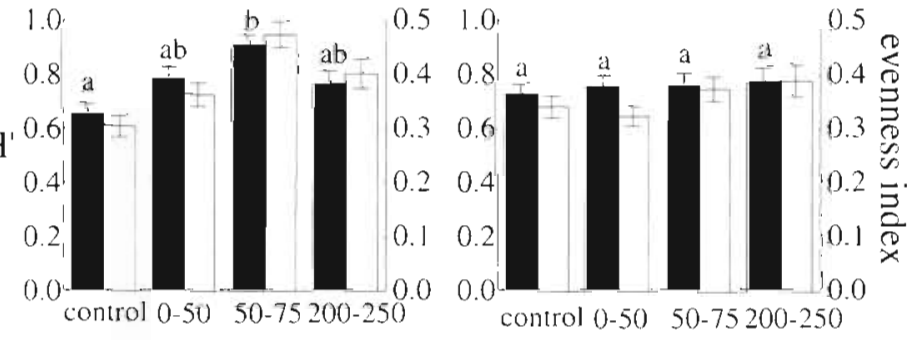

C $90-180 \mathrm{~cm}$

D $180-360 \mathrm{~cm}$

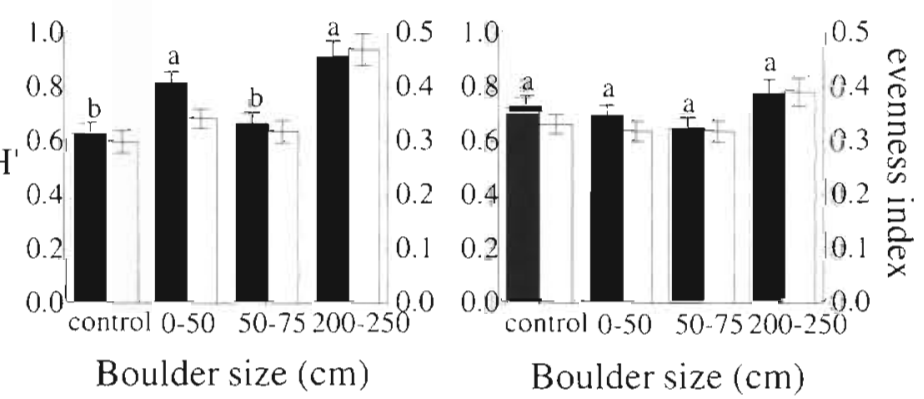

Fig. 8. Mean diversity $\left(H^{\prime}\right)$ and evenness for the 4 boulder size categories, at (A) $0-30 \mathrm{~cm}$, (B) $30-90 \mathrm{~cm}$, (C) $90-180 \mathrm{~cm}$, and (D) $180-360 \mathrm{~cm}$ rom the edge of boulders. Boulder size categories with significantly ifferent $H^{\prime}$ values are indicated by different letters. Evenness was not significantly influenced by treatments $( \pm$ SE)

velocity index. Both velocity index and invertebrate biomass decreased downstream of large boulders, and the relationship between invertebrate biomass and velocity index showed a significant increase in invertebrate biomass in the middle of the overall velocity index range (Fig. 9B). Moreover, velocity on the downstream side of large boulders was always $<15 \mathrm{~cm} \mathrm{~s}^{-1}$, and was usually $<10 \mathrm{~cm} \mathrm{~s}^{-1}$. At other orientations, velocity was $>10 \mathrm{~cm} \mathrm{~s}^{-1}$ at least $20 \%$ of the time, and often reached $15 \mathrm{~cm} \mathrm{~s}^{-1}$ (Fig. 3B). Some processes causing biomass changes (e.g. recruitment, growth, mortality) of dominant invertebrate species were positively affected by velocity over $10 \mathrm{~cm} \mathrm{~s}^{-1}$. Although invertebrate biomass was significantly influenced by our treatments, Figs. 5B \& 7B show that changes in Mytilus biomass were responsible for the observed significant patterns. The similarity between diversity and evenness patterns is further evidence that significant patterns of diversity are due to changes in the biomass of dominant species.

Flow velocity affects the structure of the boundary layer which influences invertebrate growth (Nowell \& Jumars 1984). For example, Fréchette et al. (1989) showed that, over an established mussel bed, an increase in flow velocity amplifies turbulence in the boundary layer due to the roughness of the mussel bed, preventing food depletion. Butman et al. (1994) 
modeled the relationship between flow speed and filtration rate in a mussel bed and showed that the depletion of phytoplankton was much faster at a flow velocity of $5 \mathrm{~cm} \mathrm{~s}^{-1}$ than at $15 \mathrm{~cm} \mathrm{~s}^{-1}$ These results agree with ours, which showed that around large boulders, invertebrate biomass values were lower on the downstream side of boulders, where flow velocity was $<15 \mathrm{~cm} \mathrm{~s}^{-1}$. It is possible that maximum flow velocity over the substratum limited the feeding rate of mussels downstream of large boulders, and influenced biomass levels. However, other biological processes (recruitment, emigration and mortality) affecting biomass may have been influenced by flow velocity (Gosling 1992). For instance, the relationship between flow velocity and invertebrate (mainly mussel) biomass around large boulders could also be related to the flux of larvae over the substratum or to the movement of young settlers on the subtratum.

\section{Topographic scale and community characteristics}

Spatial variability in community characteristics may be explained by different environmental and biological variables according to spatial and temporal scales (Wiens 1989, Barry \& Dayton 1991, Allen \& Hoekstra 1992, Levin 1992, Pinel-Alloul 1995). Topographic heterogeneity has been shown to have a complex nonlinear effect on benthic communities, particularly at the large scale (Archambault \& Bourget 1996), but few authors have examined the influence of heterogeneity on benthic communities at meter scales. Breitburg et al. (1995) showed that the diameter $(30$ to $75 \mathrm{~cm}$ ) of boulders increased the area of the flow wake in which fish larvae were capable of maintaining their position or swimming. Cusson \& Bourget (1997) showed that in a soft-bottom benthic community, boulder size had a negative effect on species richness, diversity and biomass (boulders $<225 \mathrm{~cm}$ ). In the present study, boulder size decreased mussel and Fucus sp. mean biomass and, thus, dominance, enhancing mean diversity and evenness. Changes in hydrodynamics as a function of boulder size could account for this effect, but the relationship between boulder size and the spatial structure of the benthic communities is complex. Indeed, the effect of boulder size on invertebrate biomass depended on the orientation, and there was a significant decrease in invertebrate biomass downstream of boulders as a function of boulder size. The interaction between boulder size and orientation could not be shown to account for the increase in $H^{\prime}$ as a function of boulder size. However, boulders created areas of reduced flow velocity on the downstream side which corresponded to lower abundance of dominant species (i.e. Mytilus and Fucus sp.), possibly favoring recruit-
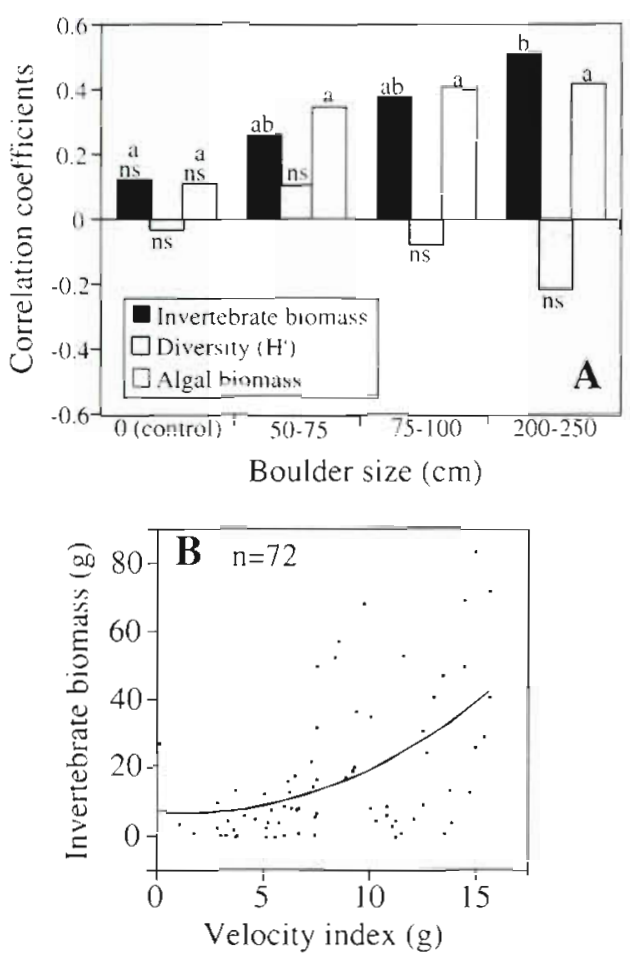

Fig. 9. Relationship between velocity index and biological variables as a function of boulder size. (A) Correlation coefficients between velocity index and biological variables (invertebrate biomass, algal biomass, $\left.H^{\prime}\right)$, as a function of boulder size. Coefficients differing significantly from one another are indicated by different letters (ns = non significant coefficient). (B) Quadratic regression model (invertebrate biomass = 0.18 (velacity index) ${ }^{2}-0.51$ (velocity index) $+7.37 ; R^{2}=0.274$; $\mathrm{p}<0.001$ showing the influence of velocity index on invertebrate biomass

ment or development of other species. The patterns become more pronounced with greater boulder size, and may account for consistent and significant biological patterns around large boulders, and the observed decrease of invertebrate biomass and increase of diversity with boulder size. Indeed, the topographic gradient (height above zero tidal level) and heterogeneity (boulder size) can be used to predict the spatial pattern of mean algal biomass (Fig. 6).

\section{Conclusion}

Understanding and modeling how spatial scales affect or modulate the response of organisms to heterogeneity in their environment is becoming a central problem in ecological research. In marine habitats, small-scale topography has been shown to influence the settlement process via hydrodynamics (Harvey et al. 1995, Grégoire et al. 1996, Lemire \& Bourget 1996). We examined the relationships between biomass, 
hydrodynamics, and boulder size. Our results showed that topographic features such as boulders locally modify the patterns of flow velocity, biomass, and diversity. We also highlighted the influence of boulder size (topographic scale) on these patterns. Finally, we have shown that the strength of the relationship between biomass and an index of flow velocity increased with boulder size, confirming a scale-dependent cascade of influences linking topography, hydrodynamics and biomass

Acknowledgements. We acknowledge S. Petitjean and F. Comi for their help on the field. We also thank M. Fréchette (Institut Maurice-Lamontagne, Fisheries and Oceans Canada) for laboratory facilities while in the field, and G. Daigle, département de mathématiques et de statistique, for his help with statistical analysis. This research was supported by a NSERC grant to E.B. and NSERC and FCAR scholarships to F.G. This is a contribution to the program of GIROQ (Groupe Interuniversitaire de Recherches Océanographiques du Québecj.

\section{LITERATURE CITED}

Abelson A (1994) Hydrodynamic impediment to settlement of marine propagules, adhesive-filament solutions. Limnol Oceanogr 39:164-169

Abelson A, Miloh I, Loya Y (1993) Flow patterns induced by substrata and body morphologies of benthic organisms, their roles in determining availability of food particles. Limnol Oceanogr 38:1116-1124

Allen TFH, Hoekstra T (1992) Toward a unified ecology. Columbia University Press, New York

Alvarez A, Joaqun T, Holloway G, Elby M. Beckers JM (1994) Effect of topographic stress on circulation in the western Mediterranean. J Geophys Res 99:16053-16064

Archambault $D$, Bourget $E$ (1983) Importance du régime de dénudation sur la structure et la succession des communautés intertidales de substrat rocheux en milieu subarctique. Can J Fish Aquat Sciences 40:1278-1292

Archambault P, Bourget E (1996) Scales of coastal heterogeneity and benthic intertidal species richness, diversity and abundance. Mar Ecol Prog Ser 136:111-121

Barry JP, Dayton PK (1991) Physical heterogeneity and the organization of marine communities. In: Kolasa JS, Pickett TA (eds) Ecological heterogeneity. Springer-Verlag, New York, p 270-320

Bergeron P, Bourget E (1986) Shore topography and spatial partitioning of crevice refuges by sessile epibenthos in an ice disturbed environment. Mar Ecol Prog Ser 28:129-145

Boose ER, Foster DR, Fluet M (1994) Hurricane impacts to tropical and temperate forest landscapes. Ecol Monogr 64 : $369-400$

Bourget E, Archambault D, Bergeron P (1985) Effet des propriétés hivernales sur les peuplements épibenthiques intertidaux dans un milieu subarctique, l'estuaire du Saint-Laurent. Nat Can 112:131-142

Bourget E, DeGuise J, Daigle G (1994) Scale of substratum heterogeneity, structural complexity, the early establishment of a marine epibenthic community. J Exp Mar Biol Ecol 181:31-51

Breitburg DL, Palmer MA, Loher T (1995) Larval distributions and the spatial patterns of settlement of a oyster reef fish: responses to flow and structure. Mar Ecol Prog Ser 125 : $45-60$

Butman CA (1986) Larval settlement of soft-sediment invertebrates: some predictions based on an analysis of near-bottom velocity profiles. In: Nihoul JCJ (ed) Marine interface ecohydrodynamıcs. Elsevier, Amsterdam, pp 487-513

Butman CA (1987) Larval settlement of soft-sediment invertebrates: the spatial scales of pattern explained by active habitat selection and the emerging role of hydrodynamical processes. Oceanogr Mar Biol Annu Rev 25:113-165

Butman CA, Fréchette M, Geyer WR, Starczack VR (1994) Flume experiments on food supply to the blue mussel Mytilus edulis L. as a function of boundary-layer flow. Limnol Oceanogr 39:1755-1768

Chabot R, Bourget E (1988) Influence of substratum heterogeneity and settled barnacle density on the settlement of cypris larvae. Mar Biol 97:45-56

Cusson M, Bourget E (1997) The influence of topographic heterogeneity and spatial scales on the structure of the neighbouring intertidal endobenthic macrofaunal community. Mar Ecol Prog Ser 150:181-193

Denny MW (1988) Biology and the mechanics of the waveswept environment. Princeton University Press, Princeton, NJ

Dionne JC (1972) Caractéristiques des blocs erratiques des rives de l'estuaire du Saint-Laurent. Rev Géographie Montréal 26:125-152

Drapeau G (1990) Nearshore sediment dynamics in the St Lawrence estuary. In: Silverberg N, El-Sabh M (eds) Oceanography of a large-scale estuarine system, the StLawrence. Springer-Verlag, New York, p 130-154

Dutilleul P (1993) Spatial heterogeneity and the design of ecological field experiments. Ecology 74:1646-1658

Eckman JE (1979) Small-scale patterns and processes in a soft-substratum intertidal community. J Mar Res 37 : $437-457$

Eckman JE (1983) Hydrodynamic processes affecting benthic recruitment. Limnol Oceanogr 28:241-257

Ferrier G, Davies PA, Anderson JM (1996) Remote-sensing observations of a vortex street downstream of an obstacle in an estuarine flow. Int J Remote Sens 17:1-8

Fortin MJ, Drapeau P. Legendre P (1989) Spatial autocorrelation and sampling design in plant ecology. Vegetatio 83 : 209-222

Fréchette M, Butman CA, Geyer WR (1989) The importance of boundary-layer flows in supplying phytoplankton to the benthic suspension feeder, Mytilus eduls L. Limnol Oceanogr 34:19-36

Frontier S, Pichod-Viale D (1993) Ecosystèmes: structure, fonctionnement, évolution. Masson, Paris

Garrity SD (1984) Some adaptations of yastropods to physical stress on a tropical rocky shore. Ecology 65:557-574

Garrity SD, Levings S (1.981) A predator-prey interaction between two physically and biologically constrained tropical rocky shore gastropods: direct, indirect and community effects. Ecol Monogr 51:267-286

Genin A, Dayton PK, Lonsdale PF, Spiess FN (1986) Corals on seamount peaks provide evidence of current acceleration over deep-sea topography. Nature 322:59-61

Gosling E (ed) (1992) The mussel Mytilus: ecology, physiology. genetics and culture. Developments in aquaculture and fisheries science, Vol 25. Elsevier, Amsterdam

Gosselin LA, Bourget E (1989) The performance of an intertidal predator Thais lapillus, in relation to structural heterogeneity. J Anim Ecol 58:287-303

(iranger RA (1995) Fluid mechanics. Dover, New York

Cirégoire Y, Bourget E, Verrette JL (1996) Deposition of mim- 
ics of planktonic invertebrate larvae on simple: and complex substrata in flume flows. Mar Ecol Prog Ser $13 j$ : $89-100$

Grimm V (1994) Mathematical models and understanding in ecology. Ecol Model 75:641-651

Grimm V, Frank K, Jeltsch F, Brandl R, Uchmanski J, Wissel C (1996) Pattern-oriented modeling in population ecology. Sci Total Environ 183:151-166

Harvey M, Bourget E (1997) Recruitment of marine invertebrates onto arborescent epibenthic structures: active and passive processes acting at different spatial scales. Mar Ecol Prog Ser

Harvey M, Bourget E, Ingram RG (1995) Experimental evidence of passive accumulation of marine bivalve larvae on filamentous epibenthic structures. Limnol Oceanogr 40: $94-104$

Hastings HM, Sugihara G (1993) Fractals: a user's guide for the natural sciences. Oxford University Press, Oxford

Johnson LE (1994) Enhanced settlement on microtopographical high points by the intertidal red alga Halosaccion glandiforme. Limnol Oceanogr 39:1893-1902

Jumars PA, Nowell ARM (1984) Fluld and sediment dynamic effects on marine benthic community structure. Am Zool 24:45-55

Komatsu T, Kawai $H$ (1992) Measurements of time-averaged intensity of water motion with plaster balls. J Oceanogr 48 $353-365$

Lemire M, Bourget E (1996) Substratum heterogeneity and complexity influence micro-scale selection of Balanus $\mathrm{sp}$ and Tubularia crocea larvae. Mar Ecol Prog Ser 135:77-87

Levin SA (1992) The problem of pattern and scale in ecology Ecology 73:1943-1967

Levin SA, Grenfell B, Hastings A, Perelson AS (1997) Mathematical and computational challenges in population biology and ecosystems science. Science 275:334-343

Lighthill J (1986) An informal introduction to theoretical fluid mechanics. Clarendon Press, Oxford

McCormick MI (1994) Comparison of field methods for measuring surface topography and their associations with a

Editorial responsibility: Otto Kinne (Editor),

Oldendorf/Luhe, Germany tropical reef fish assemblage. Mar Ecol Prog Ser 112 $87-96$

Muus BJ (1968) A field method for measuring 'exposure' by means of plaster balls. Sarsia 34:61-68

Nowell ARM, Jumars PA (1984) Flow environment of aquatic benthos. Annu Rev Ecol Syst 15:303-328

Pannatier Y (1996) Variowin: software for spatial data analysis in 2D. Springer-Verlag, New York

Pinel-Alloui B (1995) Spatial heterogeneity as a multiscale characteristic of zooplancton community. Hydrobiologia 300/301:17-42

Rankin KL, Mullineaux LS, Geyer WR (1994) Transport of juvenile gem clams (Gemma gemma) in a headland wake. Estuaries 17:655-667

SAS (1988) SAS language, version 6. SAS Institute Inc, Cary, $\mathrm{NC}$

SAS (1994) JMP users guide, version 3. SAS Institute Inc, Cary, NC

Schneider DC (1994) Quantitative ecology: spatial and temporal scaling. Academic Press, San Diego

Sokal RR, Rohlf JF (1981) Biometry. W H Freeman and Company, New York

Thompson TL, Glenn E (1994) Plaster standards to measure water motion. Limnol Oceanogr 39:1768-1779

Tilman D, Kareiva P (1997) Spatial ecology: the role of space in population dynamics and interspecific interactions. Princeton University Press, Princeton

Tritton DJ (1988) Physical fluid dynamics. Clarendon Press, Oxford

Vogel S (1.984) Drag and flexibility in sessile organisms. Am. Zool 24:37-44

Wiens JA (1989) Spatial scaling in ecology. Funct Ecol 3: $385-397$

Wolanski E, Hammer WM (1988) Topographically controlled fronts in the ocean and their biological influence. Science $241: 177-181$

Worcester SE (1995) Effects of eelgrass beds on advection and turbulent mixing in low current and low shoot density environments. Mar Ecol Prog Ser 126:223-232

Submitted: September 19, 1997; Accepted: June 12, 1998

Proofs received from author(s): August 17, 1998 